\title{
WILLIAM JAMES AND ZEN
}

\section{VAN METER AMES}

Universily of Cincimati

William James (1842-1910), who is perhaps the most famous American psychologist and philosopher, owed much to his father. The father was a very religious man but not in sympathy with the Protestant churches around him, because of their great emphasis upon individual salvation. He thought it made people too self-centered to be worrying about saving their own souls. He wanted men to develop beyond self-interest and become devoted to what he called "divine-natural humanity," or the universal man which was the same as God. He believed that God is in man not as an individual self or private person, but in all mankind as society. He would agree with Zen's rejection of ego-entity in order to realize the BuddhaNature of the cosmic Self. He would understand the indifference to distinctions of right and wrong which may be found in Zen. He thought morality much less important than religion, because morality seemed centered in the separateness of the self. He wanted men to turn away from their little separate selves toward the social, the common, the universal. To him ultimate reality was a monism, an absolute oneness.

This is where his son disagreed. William James preferred to think of the world as pluralistic, with real variety and differences in it. William James did not want differences, especially moral differences, to be swallowed up and lost in a monism. He said that if the world were all one, the evils which appear in moral experience would not be real. In moral effort they are very real, and men need to think they are real in order to fight them. He called this the "healthy-minded" view, because it requires health and strength to fight against evil and wrong. It takes energy. When William James was tired he was in a mood to feel the attraction of his father's conviction that evil is not real in the ultimate oneness. But William James called this the mood of failure and fear. It discourages human effort and leads men to look for help outside themselves in a supernatural way. Then action is given up for contemplation. Well-doing becomes only a hollow substitute for well-being.

Father and son both had a warm sense of the worth of each human being. But to the father the worthy thing for a person was to outgrow selfhood. The son wanted each self to develop fully, through a free fellowship with other selves. But if his father's monism were true, then individuality would seem to be sacrificed. The charm of conversation would be lost if individual differences were not important. The brilliant talk at the James dinner table would be an illusion. The surprising spontaneous turns in Zen dialogues would also lose their value.

The father came to philosophy by way of theology. The son came by way of art at first. He was an artist, then a natural scientist; then he went from being a medical doctor to being a physiologist; later a psychologist, and finally a philosopher. He fused his later interests with the earlier ones and pressed on, looking for the larger meaning of whatever he studied. He not only rejected his father's monism of theology or religion; also the monism of materialism. That is, William James refused to think of man as mere matter, as just an 
automaton or a machine. He regarded man as a conscious intelligence fighting for ends or purposes. This would seem to set man apart from other beings in the evolution of nature. But William James hoped to show how even man's distinctive consciousness belonged to nature instead of breaking from nature.

In his pioneering chapter on "The Consciousness of Self" in The Principles of Psychology James began to work away from the idea of the mind or self as a conscious entity dualistically set apart from other aspects of life. He came to think of the human mind and self as not a thing or entity or substance but as a way of behaving. But he went through several stages before reaching this insight, which approaches the Buddhist view.

When he tried to look within at his own self what he found was not a spectator and not a disembodied something, but a feeling of bodily processes going on. He could say that whatever the self was it was active. And he felt that its activity had a rhythm of being furthered and hindered. But when his introspective glance turned quickly enough "to catch one of these manifestations of spontaneity in the act," all he could feel was bodily processes, mostly in his head. "In consenting and negating, and in making a mental effort," he found that the "opening and closing of the glottis play a great part.... intercepting my breath instantaneously at every mental hesitation or felt aversion to the objects of my thought, and as quickly opening, to let the air pass through my throat and nose, the moment the repugnance is overcome...." His conclusion was:" our entire feeling of spiritual activity... the nuclear part of the Self, intermediary between ideas and overt acts, would be a collection of activities physiologically in no essential way different from the overt acts themselves."

James could not be satisfied to think that the self is only movements in the head and throat. To identify the thinking self with these movements was to get away from the old notion of consciousness as an entity, but did not go far toward finding what the self positively is. James himself continued to cherish the sense of something more soulful in the self, even if that must be inaccessible to psychology and philosophy. From being a member of the lively James family and enjoying their conversation, he could not overlook the sparkle of personality which is certainly more important than the way the air passes through the glottis. Earlier in the same chapter he had been closer to the heart of the matter when he spoke of "our ability to argue and discriminate." He linked this ability with "our moral sensibility and conscience" and "our indomitable will." Adjustments of muscle and breath might be closely related to the self in this human sense, but could not be all there is to it.

James did establish that the self is not a pure knower or onlooker but a process or set of processes, striving for ends. He saw that the self is a kind of functioning or behaving. This makes him a behaviorist, but not in the sense of John Watson who tried to limit human nature to behavior which can be observed from the outside, as in watching animals. James used introspection and did not give up the "inner" aspect of the self after trying to describe it behavioristically.

He felt that religious experience suggests more than research can establish or explain about the self. But subsequent research has come much closer to the real nature of the self along the line of his own suggestion that the reality of the self is in the ability "to argue and discriminate." This ability shows that bodily processes become the activities of a self only 
when they take on a symbolic character-when they become signs or indications. Later American philosophers (George H. Mead, John Dewey, Charles Morris) would go beyond James in explaining how the biological organism rises to the level of becoming a self through the use of symbols; that is through movements or gestures which enable one organism to communicate with others. The self appears when its movements can be used as signs and symbols in social relationships. The life of the self is in expression, in communication, in conversation where the ability arises and develops "to argue and discriminate."

If the use of language is the central fact about the self in its relation with other selves, it is clear that the self is more than body. Yet the self is not disembodied. It does not appear apart from biological organisms, and these must have highly developed nervous systems before it is possible to use gestures and understand them as language. It is through the power to use gestures as signs, as words, that a self develops and is able to pursue ends intentionally or consciously. Then the purpose of education, government and civilization, is in enabling the self to develop through expression and communication. Then the great conversation, of the arts and sciences can unfold.

This development is purposeless, in the Zen sense of not being for the sake of anything beyond life but for the sake of a fuller life, day by day and moment by moment. The Zen realization that life is for life, that experience is the answer to its own problems, that this moment is the most real reality, and that what it comes to comes back to the mind : this is what William James found in his quest for the mind or self. Zen also "approaches the origin of the mind," as Professor Masunaga says (The Soto Approach to Zen, p. 59). But, when he adds that in this approach Zen "directly experiences the absolute," this sounds more like the father of William James than like William James himself who opposed the idea of the absolute as swallowing up the individuality of the human self. If the idea of the absolute is essential to Zen, this would seem to separate Zen from the scientific spirit of James, which was inquiring and searching, step by step, without any thought of reaching an absolute. Yet, in his religious feeling and in his religious studies, James had the Zen sense that immediate experience comes first and last. This would seem to be what Nyogen Senzaki means in saying that nothing is except what there is: "no this, no that, no I and no you" (Buddhism and Zen, p. 57.) Both for James and for Zen, however much they differ, the question is what is there, and this is the answer.

James agrees with Zen that experience is to be defended against philosophy-against abstract explanations which come after first-hand experience. Yet James, like Zen, wants a philosophy that will come close to life. So, in The Varieties of Religious Expcrience, he makes considerable use of cases, of confessions, to reveal "something more primordial than reason" and get down to "living moments." He values religion for belonging to this "very inner citadel of human life." He says this cannot be translated into the conceptual terms of a philosophy of religion, because that would mean trying to be rational about the irrational, to make sense of what can only be sensed. Really, nothing can be made of religious experience except what it is. So James once said he felt closer to the simple piety of popular sects (who did not try to philosophize) than to the religious liberalism of intellectuals who tried to explain everything, and were in danger of explaining everything away. 
There is some filial piety or "ancestor worship" in this. James wanted to show his skeptical friends that his father's deep interest in religion was justified. William Jamescould not accept his father's monistic absolutism. The son wanted a pluralistic universe open to risk and adventure. But in some moods he also wanted reassurance that, after all, the self would be safe. This may be inconsistent. But it is human and honest. In notes for his book on the Varieties he wrote: "Remember that the whole point lies in really believing that through a certain point or part in you you coalesce and are identical with the Eternal. This seems to be the saving belief both in Christianity and in Vedantism" (quoted in R. B. Perry, The Thought \& Character of William James, Vol. II, p. 331). And it is the same in Zen. James sees that it is not merelyWestern. He wants to join the "healthy-mindedness" of his pluralism with the "sick soul's" demand for security in his father's monism. At times the son wants the comfort of the father's monism without the monism. This is one aspect of William James' essay on "The Will to Believe," in which he observes that believing something can help to bring it about. He meant that a man has a better chance of jumping a ditch or winning a fair lady if he believes he can. Confidence can make a difference. And he thought it helped morale to believe in God.

But, in addition to the will to believe, he had the will to think, and he thought monism untenable, because it would make the fight against evil unreal. Yet he recognized that even without such theological or intellectual grounds for reassurance as his father had, men could have a direct and immediate sense of reassurance. To him this experience was primary. He called it mystical and he found that many ordinary people had it quite naturally. The experience was the important thing. The explanation, whether it could be found or not, was secondary. So it is not serious if explanation is unsuccessful. The saving fact is that men can feel saved. To try to explain it by saying that the individual is in the Eternal is only a way of emphasizing and dramatizing the fact of feeling saved, without really explaining it.

The Zen men are aware of this and the humor of it. When they are asked what Zen is, what Buddha is, or why Bodhidarma came out of the West, they may make fun of the question by saying something nonsensical, or just laugh. They know in their own experience that somehow Buddha is what men are; also that whatever men can imagine, Buddha is.

For James the essence of religion is in finding release from uneasiness. This is expressed in various cultural traditions in different ways. James was sympathetic with the supernaturalist terminology of Christianity, but he had the Zen-sense of the all-importance of first-hand experience. The saving thing was an experience. It was not necessary to bring in an outside savior. Neither was it necessary to think of the individual himself as an inside agent or actor to cause or have the experience. It was enough to say that a kind of experience was going on which could become highly conscious and precious through the use of language.

William James wrote a famous paper with the title, "Does Consciousness Exist?" Consciousness, or intelligence or mind, came to mean for him the kind of behavior which takes place in using language, pursuing ends, solving problems, making decisions, or in having what is called religious experience. To set up a thinker to do the thinking, which is intelligent or conscious functioning, would be like supposing a walker inside a man to do his walking, or a smoker in him to do his smoking. The man himself is his talking, walking, and thinking 
activity. When something is going on or happening, it does not need a "happener" to make it happen. The idea of an agent behind every action is no longer an acceptable explanation. If there has to be a soul in a man to make him alive, or a ghost in him to make him go, then there would have to be a ghost inside the ghost to make the ghost go, and so on. Electricity is no longer thought of as something to explain electric happenings. Electricity now is only a name for electric events. We live in a dynamic world of events of great swiftness, a world that is on the go while we are on the move. The driver of an automobile does not drive it in the sense of pushing it. He only guides it, gives it more fuel or puts on the brakes. An aviator does not $f l y$ an airplane. He flies in it and with it. And it does not fly by itself but in and with the air. Only a flier knows how active the air is, with its currents, holes and jolts.

In the modern world of speed and power anything still or standing is an abstraction from action, And every action is interaction and transaction. Nothing stands or moves alone. Everything and everyone is involved. If there is any rest it is on the wing, or it is only a landing, or what William James called a perching between flights. For James the world was flow and flux, as in the Buddhist idea of impermanence.

We lose nothing by James' denial of a soul-entity or a consciousness-stuff, since the self for him is the very center of what experience is for each of us. It is the warm and breathing body that each human being is to begin with and end with. It is a size and shape and way of walking especially a way of talking. It is a trick of smiling, of gesturing, a knack of doing things a little differently. It is all this which a photograph suggests and a friend fills in from memory and affection. A self includes the clothes that go with it, the house and neighborhood it lives in. Though a self is lodged in a body so snugly that it is the body, the same is true of the house it lives in. A house belongs to a self not only in being owned and inhabited, but in being cherished and furnished not quite as it would be by another. And if we can speak of the bodily self as "it,"we feel that we should use a personal pronoun when we recognize how much more than a body a self is. We see that in having friends as well as parents and children the self is what we mean by a person; not in being detached from his organic center and located in some abstraction above it; but in having interests and activities-that is, in doing things. It is still in or with the body that things are done. As the body goes walking or swimming or skiing, the body goes to college. The body writes and reads. Its eyes see who is at the door; its ear listens at the telephone. If it seems strange to speak of a body as doing these things, our speech reminds us that everybody does them. When William James tried his best to call on himself and find himself at home he found his "Self of selves" in his breathing, in movements of his head and chest. The self, the person, the human being is more than body but is there in the body, as well as in the house or in the country. In and beyond the body, the self is in the world. It breathes the environment in and out, and is part of its own environment.

James cared so much about persons (however their personality is explained) that he disliked any government or institution or philosophy which was unfair to persons. In spite of all differences in people he agreed with his father that there is something too deep and valuable in immediate experience not to be shared by all men in their common humanity. Not only do all men feel heat and cold and hunger. The main thing for James is that everyone feels 
depressed or elated in relation to the universe. But he thought a full life would include both moods. So he felt more sympathy for the "sick souls" who needed to be "twice born" (like his father) than for the "healthy-minded" people for whom it was enough to be "once born." At the same time, feeling himself to be a sick or tender soul like his father, William James could envy the healthy ones whom he also called tough-minded, who are naturally cheerful. But he felt that the "tough" ones would miss the religious experience, if he was right that it consisted in shifting from uneasiness to a sense of release.

So James thought it better not to be relieved of uneasiness in the first place by his father's monism. Yet the son recognized that the reason the father clung to the absolute safety in monism was that he began with a very uneasy need of it. There is a similar situation.in thought about Zen. Men would not need to be assured of having the Buddha nature if they did not feel the lack of it in their own inadequacy. It is paradoxical that they should need to have an experience of awakening to their Buddha nature if they already have it. On the other hand, it is a wonderful thing if they can discover that they already have it and do not need to attain it. This is the point of Dogen's denial of a difference between training and enlightenment. As Professor Masunaga says, the right attitude of zazen frees a man from "the wait for enlightenment and the wish to become a Buddha" (The Soto Approach to Zetr, p. 64).

Like Zen, the philosophy of William James has a practical impact. It instils an attitude which helps a man to live. It is a fight talk. It tells him that his own self is a process, a project to be lived and rightly lived; and that his world is not a place outside him, unaffected by him, but depends upon his attitude and action, bis interaction and interdependence with other men and things. So a life worth having is a fight for ends which are found in selfrealization. The struggle may be difficult, may be a losing one. There is real possibility of tragedy. But men must learn to be calm and brave even in defeat and death. They must discover within themselves a source of release and reassurance in the midst of uncertainty and uneasiness.

MS. received III 23, 59.

Van Meter Ames (1898-) Professor of Philosophy, Univ. of Cincinnati, Fulbright Research Professor of Philosophy in Komazawa University (which belongs to the Soto sect of Zen Buddhism), Tokyo, 19581959. 